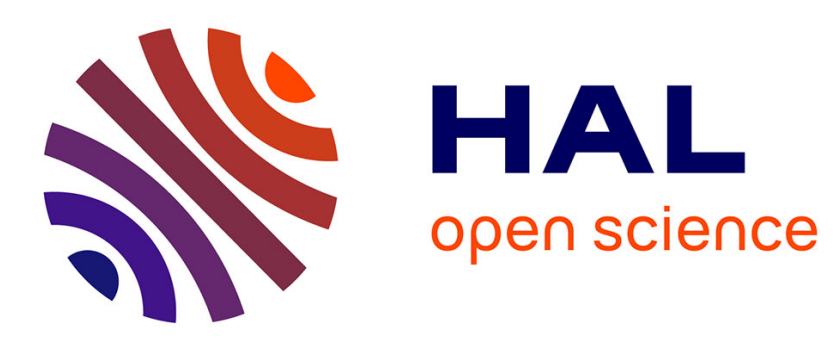

\title{
Beyond church and court: city musicians and music in Renaissance Valladolid
}

\author{
Cristina Diego Pacheco
}

\section{To cite this version:}

Cristina Diego Pacheco. Beyond church and court: city musicians and music in Renaissance Valladolid. Early Music, 2009, XXXVII (3), pp.367-378. 10.1093/em/cap045 . hal-01215298

\author{
HAL Id: hal-01215298 \\ https://hal.science/hal-01215298
}

Submitted on 19 Nov 2015

HAL is a multi-disciplinary open access archive for the deposit and dissemination of scientific research documents, whether they are published or not. The documents may come from teaching and research institutions in France or abroad, or from public or private research centers.
L'archive ouverte pluridisciplinaire HAL, est destinée au dépôt et à la diffusion de documents scientifiques de niveau recherche, publiés ou non, émanant des établissements d'enseignement et de recherche français ou étrangers, des laboratoires publics ou privés. 


\section{CRISTINA DiEGo PACHECO}

\section{BEYOND CHURCH AND COURT: CITY MUSICIANS AND MUSIC IN RENAISSANCE VALLADOLID}

The study of urban music has often been limited to Court or Church studies and, as a result, the analysis of music and music making has been largely limited to these two particular environments. ${ }^{1}$ The ónewôvision proposed in the research presented here seeks, however, to examine the place that music occupied in the whole social system, following natural laws of association and dissociation. The role played by music in this new broader context can thus be integrated into what French historiographers have called the T̃nistory of representationsò, ${ }^{2}$ a vision associated with private or public performances and their aesthetics. As musicologists, we are seeking to broaden our knowledge in this area by contributing to contemporary interest in the musicians and music-makers in the everyday life of a Spanish town, telling the story of ñhose without historyò. ${ }^{3}$

The present article seeks to offer a documentary view of civilian life in sixteenthcentury Valladolid: this will lead us to examine how music melted into the urban tissue in order to understand more about the way music was performed, taught, sold and transmitted. Valladolid has been chosen as a striking example since it was one of the kingdomôs richest cities, and also one of Spain $\hat{Q}$ capitals under the reign of emperor Charles V; the Royal Court stayed in Valladolid for long periods of time with the longest being that between 1548 and 1559 (illus. 1).

With the presence of the Royal Court, hoards of people were drawn to the town and settled there, attracted by the wealth generated by the aristocracy and, significantly, the administration associated with the royal house. Moreover, Valladolid was very close to Medina del Campo, a town that hosted one of the most important fairs in the country, and thus many book dealers (a number of them coming from Lyons, France) settled in Medina del Campo or Valladolid in order to sell their goods.

The information presented here is largely drawn from documents held in the Provincial Historical Archive of Valladolid ${ }^{4}$ in mainly post-mortem inventories and contracts. We have also examined a number of documents at the Valladolid cathedral (a collegiate church until 1596) and different chronicles of foreign travellers. This vast corpus may well, in some cases, lack accuracy because of the complexity of the source materials, but it provides nevertheless both an extensive and private vision of musical life in this town. The methodology proposed here is cumulative and the approach mostly holistic, with the whole providing a synthesis that also draws in some cases from previous published material. ${ }^{5}$

\section{Being a musician in Valladolid}

Musicians flourished outside the Court and the Church in Spain, even though these aspects have often been overlooked in musicological research. Very few studies deal with musicians working for the aristocracy in Spain, for example, in spite of a number of clues showing that this aspect is to be compared to what happened in Italy (partly under Spanish sovereignty) at the same time. ${ }^{6}$ In Valladolid, unpublished documents preserved in civil archives show that Count of Lemos, one of the richest nobles in Valladolid at that time, employed a musical chapel since at least 1576, with theorist Francisco de Montanos as its chapel master. ${ }^{7}$ In 1571, two singers were in his service: a contralto and a bass, the latter being paid 3,208 maravedis a year. This same year, the count paid 442 maravedis to Jerónimo de Torres ñfor having sung some madrigalsò, strongly suggesting that Lemos hosted an academy or a similar group. ${ }^{8}$ The following year, the count offered two shirts to vihuelist Antonio Alvarez. ${ }^{9}$ It is thus evident, in spite of this minimal information, that the count was a 
music lover, who financed, supported and promoted music making. This can be further confirmed by the number of instruments found in the post-mortem inventory of the countess of Lemos, including some ñsmall organsò. ${ }^{10}$ The Duke of Béjar was also a patron of music as can be seen from a 1544 post-mortem inventory of his estate that includes many keyboard, stringed and wind instruments. ${ }^{11}$ The fact that he had a number of musicians in his service is also known, but only through documents showing that the Municipality hired some of them for Charles Vôs entry into Valladolid in $1517 .{ }^{12}$ We also know that the Fourth duke of Béjar (Francisco López de Zúñiga) hired a ñcompanyò of four trumpeters (Pedro de Robles, Pedro de Santiago, Lucas López and Alonso de Santiago) in 1575 with an initial salary of 5000 maravedis per year. ${ }^{13}$ The Bishop of Palencia, who lived in Valladolid as this city provided a far more invigorating environment, had English and Flemish musicians in his service, as can be seen in the contract he made for the entertainment of his guest Juan de Soto in $1583 .{ }^{14} \mathrm{He}$ obviously had a personal chapel, since another contract signed in 1583 states that the choirboys working for him (and not for the Palencia cathedral) would receive 6000 maravedis a year. ${ }^{15}$ Moreover, he bought a cítola (zither) in 1583 ñto be played by a pageò. ${ }^{16}$ And, last but not least, Claudio Cilli, marshal of the King (maréchal des logis or Marshal-of-Lodgings), was a very influential man who possessed one of the most significant fortunes in town and who also had a taste for ostentation. His 1553 post-mortem inventory attests to his being a patron of music who owned a plethora of musical instruments, such as a harpsichord, bagpipes, drums, lutes, a small organ ñwith wood pipesò (illus. 2), etc. It also shows that he had left countless books, sculptures and pictures in his personal collection. Just the sheer number of musical instruments that he possessed suggests that he was a music lover and is likely to have played one or more instruments; it is also highly possible that Cilli could have hosted an Academy, recruited musicians and maybe have received private music lessons.

Alongside these musicians engaged by patrons, other professional musicians worked in $\ddot{I}$ and forï the town. As is well known, municipalities were in charge of civil festivities and they hired professional musicians for such events. These musicians were grouped together in Valladolid under the designation ñtrompetas de Valladolidò (ñtrumpeters of Valladolidò), a municipal band some of whose members were known to have participated for long periods of time, as is the case with trumpeter Pedro de Robles who played in civic events for more than twenty years, from 1571 to $1593 .{ }^{17}$ They also had their own place available for performances and rehearsals: the ñCasa de las Chirimíasò (House of Shawms) as reported by Pinheiro da Vega, a Portuguese visitor to Valladolid at the beginning of the seventeenth century who commented that the house ñis painted and exists only for the amusement of the citizens on feast daysò ${ }^{18}$

The feast days to which he alludes are mainly royal entries, bullfights, juegos de cañas (jousts) and processions. ${ }^{19}$ The cost of these latter festivities were shared in Valladolid between the Municipality and the confraternities, and musicians could thus work between both establishments. A contract dated in 1589 shows that the same trumpeter cited above, Pedro de Robles, was hired by the Piedad Confraternity, ñwith four other companions, trumpeters and drummersò for the Good Friday processions in which the Confraternity participated. ${ }^{20}$ Amateur musicians also seem to have offered their services for the processions. We know for example that the dissolution of a ñtrumpeters bandò took place in 1582. This band had hired two atabales (drums) from María de Fonseca, widow of another band member, and the contract for the suspension of their activites confirms that they were all amateurs: two of them were corredores de caballos (horse brokers), another one a maestro de armas (maker of weapons) and the fourth one a zapatero (shoe maker). ${ }^{21}$ We have no idea of the technical competence of these musicians, but we do know that playing music during processions was supposed to have one only purpose: to reinforce the feeling of piety and gravity, even if the notes were óut of tuneô as traveler Pinheiro da Veiga points out that in 
the Piedad procession "one [person] carried the image of the Virgin covered with a black cloth to the foot of the cross where two men with their faces hidden and wearing black clothes were playing with out-of-tune trumpets, which incited great sadness and compassion". ${ }^{22}$ Pinheiro also relates that, following the procession of 10 June 1605, the cityôs trumpets, drums and shawms $\ddot{i} 24$ musicians in allï were in the main square at eleven ô̂elock, situated in the corners of the square where platforms had been erected to place them. ${ }^{23}$

Another religious ceremony for which musicians could also be hired by the Municipality $\ddot{i}$ and by the collegiate churchï was the auto de fe, a ceremony following the burning of heretics. Four autos de fe took place in Valladolid during the sixteenth century (21 $\mathrm{May}^{24}$ and 8 October $1559,{ }^{25} 28$ October 1561 and 11 October 1573 , the last ones being far less important than the first two), following a wave of repression that touched the Spanish Kingdom during the reign of Philip II. Seville and Valladolid were then the two main centres, of óneresyô but only Valladolid had a real Lutherian focus. ${ }^{26}$ Barthélemy Joly offers some information about music during the auto de fe of 8 October 1559, partly using his imagination, since he wrote his narration many years later, in 1604 . He states that at the beginning of the procession there was a trumpeter:

This convoy or sad procession starts to move forward, preceded by a hoarse-sounding trumpet, moaning more than making any sound, announcing the ceremony and demanding that an open space be left in the streets. $^{27}$

Musicians were also required for the celebration of corridas and juegos de cañas. Chronicler Laurent Vital, who accompanied Charles V on his first trip to Spain, writes of two corridas that took place in February 1518: one in the Plaza del Mercado (the market place) as was the custom, and the other at the Plaza de San Pablo where the kingô apartments were located. On 16 February 1518, the king participated in the games, preceded by ó 0 trumpeters and 30 drum playersô some of them coming from Naples, other from Salamanca, but most of them from Valladolid. ${ }^{28} \mathrm{He}$ mentions, incidentally, that they were making áo much noiseô that áhunder could not have been heardô supposing that the louder they played the better they were. Additionally, according to Pinheiro da Vega, witness of a juego de cañas at the beginning of the seventeenth century, knights arrived at the market place preceded by drummers, richly dressed in the colours of each of the two factions playing the game. The two colours could also be seen adorning the musical instruments and the horses. Once the sound of drums quelled the noise of the assembled crowd, the trumpeters arrived, also richly attired. After this presentation and once the quadrilles and their servants where correctly placed in the square, trumpeters and drummers played together to announce the beginning of the game. ${ }^{29}$ And last but not least, naumachies were organized to entertain Philip II during his 1592 visit to Valladolid at a cost 3,400 maravedis to the Municipality. The Pisuerga river was then channelled and the municipal musicians played music on a boat to entertain the king. ${ }^{30}$

Yet another category of musicians can be distinguished in Renaissance Valladolid: musicians working in the theatre. Playwright Lope de Rueda created the first Spanish theatre company in Valladolid in 1554 and in the second half of the century other Spanish companies such as đ́dos Españolesô or those of Alonso de Cisneros and Melchor de Villalba flourished in the city. These companies used to rent the patios where the plays were performed from the confraternities. Archival documents found in Valladolid confirm that musicians were employed in these companies. Usually cited on the sources only as ónúsicoôthese included Juan Díez who worked for đ́oos españolesô in 1588, Juan Vázquez de Ocampo who was employed by the company of Sebastián de Montemayor in 1589 and Juan de Villalbilla who played in the company of Gabriel de la Torre in $1594 .{ }^{31}$ As can be seen in a contract drawn up in 1604, Church musicians also appear to have been granted permission by their institutions to play in some theatrical performances. ${ }^{32}$ 
Two principal types of theatrical entertainments that were common in sixteenth-century Valladolid were the religious autos sacramentales that were performed on major feast days, and comedias that were staged throughout the entire year. The comedias were performed in the patios scattered throughout the city but also in another places for specific reasons, such as the celebrations following obtaining a licentia ubique docendi at the University. ${ }^{33}$ Little information has been found about the music used in plays, but some of documents are quite explicit. On 31 May 1545, for example, an auto sacramental (Visitación) was performed to celebrate the Visitation of the Virgin. The music included a dramatic villancico evoking the moment in which the Virgin arrrived at Saint Elizabethôs home. After this villancico and some salutations, the actress playing the role of Maria began to sing the Magnificat, followed by the other actors. ${ }^{34}$ Other accounts show that a villancico was sung during the auto óde los cautivosô (The captives) in $1545 .{ }^{35}$ Documents concerning companies found in $1577,{ }^{36}$ $1584,{ }^{37} 1588^{38}$ and $1534^{39}$ are the only ones to quote cascabeles (bells) in their inventories. Finally, a document signed in 1594 indicates the tasks that each member of a newly created company was to undertake. In this contract, Francisco de Villalta and Jusepe de Esquivel undertake to look for (or perhaps compose) new melodies to be sung during the comedies. ${ }^{40}$

\section{Playing music: owners of instruments}

The musicians mentioned above, whether amateurs or professionals and irrespective of whether they were in the employ of noblemen, the Municipality, confraternities, or the theatres, all played music for money. So, what then of those who played music for pleasure or for their leisure time? This is a large area that is yet to be studied. The purpose here is merely to show the musical instruments found in inventories of citizens of Valladolid whose main activity was not necessarily linked to music. This group mainly comprises amateurs who earned no money for playing music, but who made music at home or with friends as a pastime. To summarize this, the Table 1 provides a very general picture of the variety of musical instrument owners. ${ }^{41}$

As art historians have pointed out, pictures, paintings and books were usually reserved for the privileged nobility or the high aristocracy of the town. Music, however, seems to be more universal and was not necessarily restricted to a particular social class. Of course professional musicians owned instruments, as it is the case of ministril Pedro Crespo who worked for the collegiate church of Valladolid from around 1570 to 1589 . The inventory of his belongings, dated 9 September 1589, attests that he possessed soprano and tenor shawms, five cornettos and one jábega (Moorish flute) (illus. 3).

But other citizens who owned musical instruments, include university professors, doctors, lawyers, members of the Royal House, clerics, nobles, merchants, together with farmers, a ñdonkey renterò (ñalquilador de mulasò), etc. It would thus be accurate to imagine that music was probably one of the most common, appreciated and emulated artistic activities in sixteenth-century Valladolid.

Being the most expensive, only the nobility and the High Royal administrators could afford keyboard instruments. Drums are found in the houses of members of the lower classes, and so the drums listed in Table 1 are more the exception than the rule, since they might be more elaborate and used for processions, royal entries or corridas. Flutes appear mainly in lower-class inventories, but the vihuela and the guitar appear to have been more universal instruments since they are found in many inventories of citizens belonging to various social classes. ${ }^{42}$ Playing a musical instrument was obviously a sign of distinction that was to be emulated. It should be remembered that Barthélemy Joly, during a stay in Valladolid at the beginning of the seventeenth century, confirmed the musical tastes of noblemen in his description of the gatherings in which they met to ñake a break of cool airò in a meadow 
close to the city, the Prado, a place of ñecreation and amusementò where they used to play music:

Gentlemen approach the coaches filled with women or follow the promenade to other parts of this meadow; some amuse themselves with conversation or read a book under the shadow of trees, others listen to the concert of viols or sing themselves, tuning their voices to the sound of their guitars, wiling away their time in such gentle and laudable activities. ${ }^{43}$

\section{Teaching and learning music}

A ñnewò dimension of music education in Valladolid is that of private music lessons, ranging from the children of the nobility and the high aristocracy of the town ï since music was necessary to the ñeducation of princesò as was advocated by Machiavelli and some Spanish moralists such as Monzónï through to what might be described as the ñintermediateò population. Musicians could give lessons to the nobility as was probably the case of Francisco de Montanos with the count of Lemos. Other examples are the Count of Ribadavia who, according to a contract made in 1577, paid 408 maravedis a month to his music teacher Antonio de Segura, a musician not otherwise documented in the cathedral ${ }^{44}$. In 1567 , the Marquis of Villafranca hired a musician named Juan de Arbolancha (whose name does not appear in ecclesiastical sources) to ñserve him and teach him music wherever he wasò. This contract also specified a generous salary of 15,000 maravedis per year to be paid in three times $^{45}$. These music lessons thus allowed the nobility to play music during their spare time, as the passage from the chronicle of Barthélemy Joly attests.

Other documents indicate the terms of private contracts for music lessons: ministril Lope de Costilla was hired to teach music and the chirimía (shawm) ánd not the sackbutôto a óminorô for 2,992 maravedís in $1546 .{ }^{46}$ The contract specifies that the child was to be taught to read and write music, to sing canto de órgano (polyphony) and to play the shawm. Another similar example is a contract made on 14 May 1578, in which a cleric named Pedro Ramírez was hired to give private music lessons for two years to the son of a porter named Cosme Martínez. The contract refers specifically to teaching the boy to read plainsong and mensural notation as well as teaching him to play a polyphonic part on the viol (illus. 4).

\section{Selling and publishing music in Valladolid: instrument makers and booksellers}

Musicians and others who owned musical instruments owners probably bought them in town: demand generates supply, so it is only logical to conclude that there was a local market for instruments. We will provide a few exemples of instrument makers in Valladolid: Pedro Hernández was a castanet maker from whom we have information from 1580 until $1593 .{ }^{47}$ Far more important were the violeros (luthiers), especially in light of the prominence and popularity of stringed instruments. The violero Juan Miranda had his workshop in the Calle Cañuelo, as is revealed in a 1518 contract in which Miranda leases the building from the collegiate church. ${ }^{48}$ He died in 1528 , and the lease was transferred to his sons who continued the family business. ${ }^{49}$

In a document dated in $1536,{ }^{50}$ the violero Pedro de Arratia entered into a contract with Alonso de las Moras from Burgos in order to purchase áll the finest quality stringsôthat his wife óvas able to makeô Pedro de Arratia was no doubt related to the distinguished family of violeros in Toledo, notably Mateo de Arratia who has been amply documented by François Reynaud (illus. 5). ${ }^{51}$

Concerning music books in Valladolid, some aspects of the reception and readership have been explored in a recent monograph. ${ }^{52}$ We know for example that individuals such as cardinal Ascanio Colonna, who established himself in Valladolid in 1600, are probably linked 
to the existence of some music books in the archive of the cathedral. ${ }^{53}$ Moreover, of the seven books of vihuela music published in Spain during the period 1536-1576, three were published in Valladolid by the Fernández de Córdoba press: the books by Narváez, Valderrábano and Daza as can be seen in Table $2 .{ }^{54}$

Printers sold their own editions, as was the case of the famous Fernández de Córdoba family who printed Valderrábanoôs and Dazaôs vihuela books in Valladolid, along with the treatises of Tomas de Santa María and Francisco de Montanos who, incidentally, also owned a copy of Orphenica Lyra vihuela book by Miguel de Fuenllana published in 1554 in Seville. ${ }^{55}$ In the main, booksellers in Valladolid specialized in printed book coming from trade faires, mostly from the one held in the nearby town of Medina del Campo, which was one of the largest in Spain. Printers from Lyons were also established in Medina del Campo, and many books in Spanish were, in fact, printed in the city of Lyons to fulfil the demand for books in Spain where the printing business was less developed. These printers achieved so much success in their Spanish business that a number of printers from Lyons decided to establish themselves in Spain, among them the brothers Bonnet (called ñBenitoò in Spanish sources) and Jean-Jacques Boyer who had been partners since 1555 and who established themselves in Medina del Campo from around 1560 to 1589. The Boyers became the most prosperous book dealers of the town, establishing links with the local bourgeoisie through the marriage of Bonnet to Beatriz Delgado del Canto ï daughter of the printer Mateo del Cantoï and Jean-Jacques to Catalina de León Figueroa. At the same time they maintained their commercial links with Lyons as well as Nantes, Paris, Venice and Rome. They sold their books throughout the Peninsula (Valladolid, Salamanca, Madrid, Alcalá, Toledo, Sevilla, Granada, Palencia, Plasencia, Zamora, Pamplona, Córdoba, Burgo de Osma, Coimbra and Lisbon) as well as the Americas (Mexico and Lima). ${ }^{56}$ The 1592 inventory of ñBenitoò Boyer, first studied by Pérez Pastor, ${ }^{57}$ shows that he had books of Franco-Flemish polyphony (Josquin, Mouton, Richafort, Jean de Latre), Italian madrigals, Spanish music (Cabezón), some theory books (Zarlino, Santa María, Martín de Tapia), and also books on musical education, such as El Espejo Cristiano by Francisco de Monzón. ${ }^{58}$ This proves beyond doubt the importation of music books from Lyons to Valladolid via Medina del Campo. Other printers from the Lyons area who came to own land and shops in Medina del Campo include Pierre Landri (who worked for his famous uncle, the publisher Charles Pesnot), Guillaume Pesnot, Claude Gautier, Jean Pinat, François Lambert, Ambroise Duport, and Hilaire Benefont. ${ }^{59}$ This further explains the significant number of printed books containing foreign music available in Valladolid, and shows the extent to which the circulation of music in the Iberian peninsula was fast and fluid. The inventory of the collegiate church of Valladolid published by Anglès includes an important number of sixteenth-century foreign music, both manuscripts and prints, ${ }^{60}$ and a recently discovered seventeenth-century inventory of the same collegiate church found by Soterraña Aguirre, soon to be published, also contains many foreign music books, a fact which should not longer be of any surprise to musicologists.

Some wealthy women in sixteenth-century Valladolid also owned music books, as a monography has recently been pointed out. ${ }^{61}$ Among them, vihuela books are mentioned in the inventories of Isabel de Santisteban, daughter of the Commander of the city, and Lucía de Monroy, daughter of the marquis of Monroy. Polyphonic books (in Spanish, French and Italian) are mentioned in those of Ana Celenque, Ana de Mendoza, Catalina de Sámano. Moreover, the recent discovery of a contract signed by Montanos in Valladolid in 1565, allowing him to published four books of madrigals shows the extent to which musical repertory was practised and in demand. ${ }^{62}$

This partial view of the musical life of a sixteenth-century Spanish town can only be incomplete since it would be virtually impossible to come to a coherent synthesis given the 
limited number of documents at our disposal. Nonetheless, this modest picture shows clearly that music was not only for the rich, and of course not exclusively of the Church and the Court. Music was for all social classes in sixteenth-century Spain just as it is today in contemporary society, and our vision of urban musical life would remain incomplete if we were not to take into account the vast information and documentation concerning the musical amateurs, booksellers and teachers of the time who remain largely anonymous but remain an essential ingredient in developing an understanding of the social tissue of urban life.

\footnotetext{
${ }^{1}$ Portions of this study were delivered at the Medieval and Renaissance Music Conference (Bangor, 2008). I would like to thank warmly John Griffiths for his helpful, constructive and benevolent comments on this version.

${ }^{2}$ See, for example, Michel Vovelle, 'Histoire et représentations', in Jean-Claude Ruano-Barbolan (dir.), L'histoire aujourd'hui. Nouveaux objets de recherche. Courants et débats. Le métier d'historien, Auxerre, Sciences humaines Editions, 1999, pp. 45-49. This expression has replaced the so-called "history of mentalities" (histoire des mentalités), a movement associated with the French Annales School.

${ }^{3}$ I borrow this term from French Historians P. Ariès and G. Duby, (eds.), Histoire de la vie privée, Paris Seuil, 1985-87.

${ }^{4}$ The abbreviation used for this archival documentation is AHPV (Archivo Histórico Provincial de Valladolid). Abreviation for the collegiate church sources is ACV (Actas Capitulares de Valladolid).

${ }^{5}$ Previous works, such as B. Bennassar, Valladolid au Siècle d'Or - Une ville de Castille et sa campagne au $16 e$ siècle, Paris, EHESS, 1999 and A. Rojo Vega's El siglo de oro. Inventario de una época, Salamanca, Junta de Castilla y Léon, 1996, have been essential for this study. This article presents a part of a larger work about music in Valladolid made for our PhD (Cristina Diego Pacheco, Un nouvel apport à l'étude de la musique espagnole de la Renaissance : le manuscrit 5 de la cathédrale de Valladolid et son contexte, Paris-Sorbonne, 2005).

${ }^{6}$ Juan Ruiz is among the first researchers in Spain to study such material, as it can be seen in the article to be found on this Early Music volume.

${ }^{7}$ According to Robert Stevenson ("Montanos", in New Grove Dictionary of Music and Musicians, vol. 17, 2001, pp. 14b-15a), Montanos started working for the count in 1574, when he married the granddaughter of San Francisco de Borja. However, the collegiate church sources do not allow us to state that Montanos did stop working for this institution at that particular date. At the same time, Aizpurúa asserts that Montanos started working for the count from 1540 to 1564, which is virtually impossible since the count was born in 1548: see Pedro Aizpurúa, 'El vallisoletano Francisco de Montanos (siglo XVI), teórico musical y polifonista', Revista de Musicología, Vl/1 (1983), pp. 109-120 (113).

${ }^{8}$ AHPV , 453-184

9 Ibidem.

${ }^{10}$ AHPV, 159-3577

${ }^{11}$ See E. Russell, "Music in the House of the Third Duke of Béjar: ca. 1520-1544" in Encomium musicae. Essais in Memory of Robert J. Snow, Hillsdale, NY: Pendragon Press, 2002, pp. 285-303.

${ }^{12}$ Libro de Acuerdos, fol. 396v, July 20th 1517 and fol. 429, November 18th 1517

${ }^{13}$ AHPV, 376-418

${ }^{14}$ AHPV, 395-364

${ }^{15}$ Ibidem

${ }^{16}$ AHPV , 433-999

${ }^{17}$ AHPV 450-122 (1571) to AHPV 694-85 (1593)

18 "Es pintada y hecha solamente para alegrar a la gente los días festivos", Pinheiro da Vega, Fastiginia o fastos geniales (1605-1608), modern edition by Narcisso Alonso Cortés (Valladolid, 1973), 177. See also Agapito y Revilla, "La Casa de las Chirimías de Valladolid", Boletín de la Sociedad Castellana de excursiones, 1879.

${ }^{19}$ See Tess Knighton and Came Morte García, 'Ferdinand of Aragón's entry into Valladolid in 1513: the triumph of a Christian King', Early Music History XVIII (1999), pp. 119-163. See also Soterraña Aguirre, 'Music and Court in Charles V's Valladolid', Kisby, Fiona (ed.), Music and Musicians in Renaissance cities and towns (Cambridge, 2001) 106-117.

${ }^{20}$ AHPV, 859-81

${ }^{21}$ AHPV , 518-28
} 
22 'Esta traía la de Nuestra Señora al pie de la cruz, cubierta con un velo negro; delante dos trompetas destemplados con los rostros cubiertos y enlutados, que mueven a mucha tristeza y compasión', quoted by Narcisso Alonso Cortés, Fastiginia o fastos geniales, p. 44.

${ }^{23}$ 'A las once vinieron los trompetas, atabales y chirimías de la ciudad, que son 24 [...] que se repartieron a las cuatro esquinas de la plaza, donde tenían sus palenques'. Ibid., p. 124.

${ }^{24}$ According to some Historians, this Auto took place on 29 May. See Henry Kamen, La Inquisición española, (Barcelona, 1992) 4th ed., p. 104.

${ }_{25}^{25}$ Madrid, Biblioteca Nacional, 2031-G115, fol. 9, and G209 fols. 67 and 109, cited in Bartolomé Bennassar, Valladolid, p. 451.

${ }^{26}$ Kamen, La Inquisición española, p. 104.

${ }^{27}$ '[...] l'ordre de ce convoi ou triste acte commence à s'avancer; et premièrement, une rauque trompette, gémissante plus tôt qu'elle ne résonne, avise tout le monde d'être en attention et à faire largue'. Bartolomé et Lucile Bennassar, Le voyage en Espagne (Paris, 1998), p. 845.

${ }^{28}$ Laurent Vital, Premier voyage de Charles Quint en Espagne de 1517 à 1518, cited in Bennassar, Le voyage, p.

7.

${ }^{29}$ Alonso Cortés, Fastiginia o fastos geniales, p. 52.

${ }^{30}$ AHPV, 1023, n.f.

${ }^{31}$ Mariá Antonia Virgili Blanquet, 'Valladolid' in Diccionario de la Música Española e Iberoamericana, Madrid, SGAE, 2002, p. 682a.m

32 'Acuerdo con la ciudad sobre los Autos de las fiestas del Corpus', ACV-June 2nd 1604.

${ }^{33}$ AHPV, 694-24

${ }^{34}$ AHPV, 230-127

${ }^{35}$ AHPV, 230-128

${ }^{36}$ AHPV, 549-82 ('from the company of Gaspar de Oropesa').

${ }^{37}$ AHPV, 717-11 ('to be used for a Corpus Christi dance').

${ }^{38}$ AHPV, 755-763 ('for the Comedy of Nuestra Señora del Rodario').

${ }^{39}$ AHPV, 502-1055.

${ }^{40}$ AHPV, 694-159.

${ }^{41}$ For a more detailed list and more information on inventories, see Cristina Diego Pacheco, Un nouvel apport. chap. I. This study will be published soon.

${ }^{42}$ See John Griffiths, 'At court and at home with the vihuela de mano', in Journal of the Lute Society of America 22 (1989), pp. 1-27 and 'Esteban Daza: a gentleman musician in Renaissance Spain' Early Music XXII (1995), pp. 437-448.

${ }^{43}$ 'Les cavaliers côtoient la botte d'un carosse plein de dames ou suivent la promenade en autre endroit de ce préau; les uns s'entretiennent de discours ou lisent un livre sous la feuillée, autres écoutent le concert de violes ou bien chantent eux-mêmes, accordant leur voix avec le son de leurs guitares, passant ainsi le temps à ces gentils et louables exercices' (Bennassar, Bartolomé et Lucile, Voyages...p. 886).

${ }^{44}$ AHPV, 170-3266

${ }^{45}$ AHPV, 286-421

${ }^{46}$ AHPV, 99-431

${ }^{47}$ AHPV, 607-3; 7698-2104

${ }^{48}$ Archivo Histórico Nacional, Madrid, sección clero, protocolo 1, 1518, fol. 250: 'contrato de arrendamiento de una casas que posee la Igla Santa Maria la Mayor en el Cañuelo a favor de Juan de Miranda violero'.

${ }^{49}$ Archivo Histórico Nacional, Madrid, sección clero, protocolo 7, 1528, fols. 458-463: 'arrendamiento de unas casas por los hijos de Juan de Miranda, violero, difunto'.

${ }^{50}$ AHPV, 92-529/530

${ }^{51}$ François Reynaud, La polyphonie tolédane et son milieu (Paris, 1996), p. 404.

${ }^{52}$ Iain Fenlon and Tess Knighton, (eds.), Early Music Printing and Publishing in the Iberian world (Kassel, 2007).

${ }^{53}$ Owen Rees, 'printed Music, Portuguese Musicians, Roman Patronage: Two Case Studies', in Early Music Printing, p. 276.

${ }^{54}$ John Griffiths, 'Printing the Art of Orpheus: Vihuela Tablatures in Sixteenth-Century Spain', Early Music Printing, p. 181.

${ }^{55}$ Griffiths, 'Printing the Art of Orpheus', p. 205

${ }^{56}$ See Claude Longeon, Une province française à la Renaissance (Saint Etienne, 1975), p. 407

${ }^{57}$ La imprenta en Medina del Campo, Madrid, 1895, pp. $456 \mathrm{ff}$.

${ }^{58}$ See Alejandro Luis Iglesias, La librería de Benito Boyer (Valladolid, 1992), p. 230. 
${ }^{59}$ Christian Péligry, 'Les éditeurs lyonnais et le marché espagnol aux XVle et XVIle siècles', Livre et lecture en Espagne et en France sous I'Ancien Régime. Colloque de la Casa Velázquez (Paris, 1981), pp. 85-93.

${ }^{60}$. Higinio Anglès, 'El archivo musical de la catedral de Valladolid', Anuario Musical 3 (1948), 59-108. The Franco-Flemish composers are: Arcadelt, Bracquet, Buissons, Clémens non Papa, Cornet, Crecquillon, De Brouck, De l'Estocart, Gombert, Jacquet, Josquin, Lassus, Leroy, Lhéritier, Lupus, Pavernage, Rogier [active only in Spain], Salmier, Turlur [active only in Spain], Turnhout, Verdelot, Willaert.

${ }^{61}$ See Pedro Manuel Cátedra and Anastasio Rojo Vega, Bibliotecas y lecturas de mujeres: siglo XVI (Salamanca, 2004).

${ }^{62}$ Cristina Diego Pacheco, 'Circulación y producción del madrigal en España durante el siglo XVI: El caso de Francisco de Montanos' Revista de Musicología (forthcoming). 